\title{
Spatial and temporal variability of nitrous oxide emissions in a mixed farming landscape of Denmark
}

\author{
K. Schelde ${ }^{1}$, P. Cellier ${ }^{2,3}$, T. Bertolini ${ }^{4}$, T. Dalgaard ${ }^{1}$, T. Weidinger ${ }^{5}$, M. R. Theobald ${ }^{6}$, and J. E. Olesen ${ }^{1}$ \\ ${ }^{1}$ Aarhus University, Institute of Agroecology, P.O. Box 50, 8830 Tjele, Denmark \\ ${ }^{2}$ INRA, UMR1091 Environnement et Grandes Cultures, 78850 Thiverval-Grignon, France \\ ${ }^{3}$ AgroParisTech, UMR Environnement et Grandes Cultures, 78850 Thiverval-Grignon, France \\ ${ }^{4}$ Euromediterranean Center for Climate Change (CMCC), Division Climate Change Impacts on Agriculture, Forests and \\ Natural Ecosystems, 73100 Lecce, Italy \\ ${ }^{5}$ Eötvös Loránd University, Department of Meteorology, 1117 Budapest, Hungary \\ ${ }^{6}$ Technical University of Madrid, E.T.S.I. Agrónomos, Dept. Agricultural Chemistry and Analysis, Madrid 28040, Spain
}

Correspondence to: K. Schelde (kirsten.schelde@ agrsci.dk)

Received: 2 December 2011 - Published in Biogeosciences Discuss.: 14 December 2011

Revised: 29 June 2012 - Accepted: 11 July 2012 - Published: 7 August 2012

\begin{abstract}
Nitrous oxide $\left(\mathrm{N}_{2} \mathrm{O}\right)$ emissions from agricultural land are variable at the landscape scale due to variability in land use, management, soil type, and topography. A field experiment was carried out in a typical mixed farming landscape in Denmark, to investigate the main drivers of variations in $\mathrm{N}_{2} \mathrm{O}$ emissions, measured using static chambers. Measurements were made over a period of 20 months, and sampling was intensified during two weeks in spring 2009 when chambers were installed at ten locations or fields to cover different crops and topography and slurry was applied to three of the fields. $\mathrm{N}_{2} \mathrm{O}$ emissions during spring 2009 were relatively low, with maximum values below $20 \mathrm{ng} \mathrm{N} \mathrm{m}^{-2} \mathrm{~s}^{-1}$. This applied to all land use types including winter grain crops, grasslands, meadows, and wetlands. Slurry application to wheat fields resulted in short-lived two-fold increases in emissions. The moderate $\mathrm{N}_{2} \mathrm{O}$ fluxes and their moderate response to slurry application were attributed to dry soil conditions due to the absence of rain during the four previous weeks. Cumulative annual emissions from two arable fields that were both fertilized with mineral fertilizer and manure were large $\left(17 \mathrm{~kg} \mathrm{~N}_{2} \mathrm{O}-\mathrm{N} \mathrm{ha}^{-1} \mathrm{yr}^{-1}\right.$ and $5.5 \mathrm{~kg} \mathrm{~N}_{2} \mathrm{O}$ $\mathrm{Nha}^{-1} \mathrm{yr}^{-1}$ ) during the previous year when soil water conditions were favourable for $\mathrm{N}_{2} \mathrm{O}$ production during the first month following fertilizer application. Our findings confirm the importance of weather conditions as well as nitrogen management on $\mathrm{N}_{2} \mathrm{O}$ fluxes.
\end{abstract}

\section{Introduction}

Atmospheric nitrous oxide $\left(\mathrm{N}_{2} \mathrm{O}\right)$ concentrations have increased during the industrial era due to increased anthropogenic emissions (Smith, 2004). Nitrous oxide acts as a potent greenhouse gas and is also involved in the destruction of stratospheric ozone. There has been an increasing effort towards quantifying and identifying the sources and sinks of $\mathrm{N}_{2} \mathrm{O}$, in order to better predict and possibly mitigate future emissions by improved management of land and resources.

Approximately $65 \%$ of atmospheric emissions of $\mathrm{N}_{2} \mathrm{O}$ originate from soils (Smith, 2004). $\mathrm{N}_{2} \mathrm{O}$ is produced in soils as an intermediate in the two contrasting microbial processes: autotrophic nitrification and heterotrophic denitrification. The contributions of these two processes to $\mathrm{N}_{2} \mathrm{O}$ emissions vary with climate, soil conditions and soil management (Skiba and Smith, 2000). Land use type and changes in the crop rotation are also particularly important in determining the rate of $\mathrm{N}_{2} \mathrm{O}$ emissions from agricultural land. For a specific crop type and soil type, it is typically found that fertilization rate, fertilizer type, timing, and cultivation play an important role in the processes controlling $\mathrm{N}_{2} \mathrm{O}$ emission from soils (Kavdir et al., 2008). $\mathrm{N}_{2} \mathrm{O}$ fluxes can be sporadic and short-lived, depending on the environmental conditions of the soil, particularly the temperature and moisture content (Smith et al., 1998; Frolking et al., 1998). Schaufler et al. (2010) observed a positive correlation of $\mathrm{N}_{2} \mathrm{O}$ fluxes with 


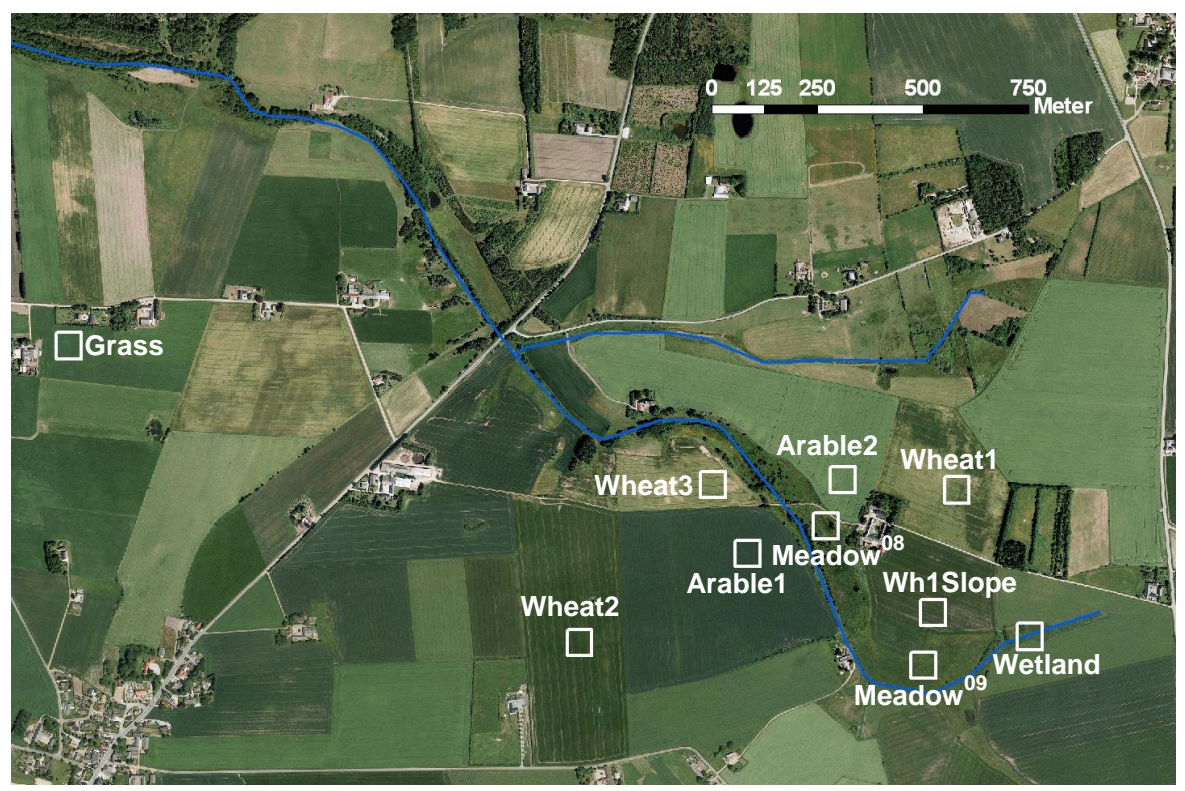

Fig. 1. Aerial photograph showing the ten locations for manual chamber measurements within the Bjerringbro landscape. Arable1 and Arable 2 were studied throughout the period 2007-2008 and the 2009 campaign. Meadow ${ }^{08}$ was studied during 2007-2008, and remaining sites were only monitored during the intensive campaign in 2009. The aerial photograph was taken in early summer of 2010.

soil moisture but found no significant relationship between emissions and $\mathrm{N}$ fertilization or $\mathrm{N}$ deposition level when analyzed over all soil moisture conditions. In short, several factors influence $\mathrm{N}_{2} \mathrm{O}$ flux patterns, and the interactions between factors make it difficult to predict emissions on a short or long time scale (Machefert et al., 2002).

Many previous inventories or measurement studies on $\mathrm{N}_{2} \mathrm{O}$ flux dynamics have focused on ecosystems or landuse types such as forests (Pihlatie et al., 2005; Kesik et al., 2005), wetland/organic soils (Maljanen et al., 2003), grasslands (Flechard et al., 2007; Chatskikh et al., 2005), or arable crop rotations in experimental plots (Petersen et al., 2006; Chirinda et al., 2010). However, there have been few attempts (Dunmola et al., 2010) to cover the mosaic of land use types encountered at the landscape scale within a single study. Pattey et al. (2006) demonstrated how micrometeorological measurement techniques can be used for the upscaling from field to landscape. While these techniques provide valuable integrated information at the landscape scale, they do not easily distinguish between contributions from individual areas. Emissions of $\mathrm{N}_{2} \mathrm{O}$ most often form a heterogeneous signal with local hotspots contributing significantly to the total flux (Matthews et al., 2010). Laville et al. (2011) concluded that the uncertainty in cumulated $\mathrm{N}_{2} \mathrm{O}$ emissions due to infrequent sampling was less than the uncertainty due to spatial variability of the sampling sites.

The current study was designed as a component of a measurement programme to estimate nitrogen fluxes and land management at the landscape level (Theobald et al., 2011) and to support modelling of the landscape-scale $\mathrm{N}$ fluxes
(Duretz et al., 2011). The objective of the study was to examine the major drivers of $\mathrm{N}_{2} \mathrm{O}$ emissions in a diverse agricultural landscape. Chamber measurements were made over a 20-month period at 10 sites in a Danish landscape to identify variations in emissions due to topography, land use or crop type, and management. During a limited period, more intensive measurements were made using additional chambers to study the effect of slurry application on $\mathrm{N}_{2} \mathrm{O}$ emissions from three wheat fields. Based on the experiences during the previous growing season, we expected to find significant fluxes of $\mathrm{N}_{2} \mathrm{O}$ following the targeted springtime manure application, which was the focus period of the intensive measurements.

\section{Materials and methods}

\subsection{Landscape and duration of experiment}

The study landscape covers an area of $6 \mathrm{~km}^{2}$ and is located near Bjerringbro, Denmark $\left(56.3^{\circ} \mathrm{N}, 9.7^{\circ} \mathrm{E}\right)$, in a mixed farming area with a mosaic of dairy, pig, and arable farms (Dalgaard et al., 2002). A stream surfaces in the area, forming a small valley in the otherwise generally flat landscape (Fig. 1). The soil type of the agricultural fields is a sandy loam with clay and organic matter contents of $12 \%$ and $3-4 \%$ in the topsoil, respectively, and $12-18 \%$ and $1-2 \%$ in the $25-50 \mathrm{~cm}$ depth interval, respectively. Narrow areas along the stream are managed or unmanaged meadow $(15 \%$ and $25 \%$ organic carbon in the $0-25 \mathrm{~cm}$ and $25-50 \mathrm{~cm}$ depth intervals, respectively) while the remaining area is used for intensive agricultural production with fields that are fertilized 
Table 1. Field names, crops and fertilization schemes at sites studied during 2007-2009. The duration of measurements (either long-term (L) or intensive campaign $(\mathrm{C})$ ) is also given.

\begin{tabular}{|c|c|c|c|c|c|c|c|c|}
\hline \multirow[b]{2}{*}{ Field } & \multirow[b]{2}{*}{ Duration } & \multirow[b]{2}{*}{$\begin{array}{l}\text { Area } \\
\text { (ha) }\end{array}$} & \multirow[b]{2}{*}{$\begin{array}{l}\text { Crop in } \\
2008 / 2009\end{array}$} & \multirow[b]{2}{*}{$\begin{array}{l}\text { Fertilizer } \\
\text { type }\end{array}$} & \multicolumn{2}{|r|}{2008} & \multicolumn{2}{|r|}{2009} \\
\hline & & & & & $\mathrm{kg} \mathrm{Nha}^{-1 \mathrm{a}}$ & Dates & $\mathrm{kgNha}^{-1 \mathrm{a}}$ & Dates \\
\hline Arable1 & $\mathrm{L}$ & 8.5 & $\begin{array}{l}\text { Spring barley/ } \\
\text { winter oilseed } \\
\text { rape }\end{array}$ & $\begin{array}{l}\text { Synthetic } \\
\text { Manure (cattle) }\end{array}$ & $\begin{array}{l}43 \\
185.5\end{array}$ & $\begin{array}{l}3 / 5 / 2008 \\
15 / 3 / 2008\end{array}$ & $\begin{array}{l}55+78 \\
53\end{array}$ & $\begin{array}{l}1 / 2 / 2009 ; 1 / 4 / 2009 \\
1 / 9 / 2008\end{array}$ \\
\hline Arable2 & $\mathrm{L}$ & 12.7 & $\begin{array}{l}\text { Winter wheat/ } \\
\text { winter barley }\end{array}$ & $\begin{array}{l}\text { Synthetic } \\
\text { Slurry (pig) }\end{array}$ & $\begin{array}{l}43+43 \\
136\end{array}$ & $\begin{array}{l}\text { 17/3/2008; 22/4/2008 } \\
20 / 3-2008\end{array}$ & $\begin{array}{l}55+88 \\
0\end{array}$ & $\begin{array}{l}1 / 2 / 2009 ; 1 / 4 / 2009 \\
-\end{array}$ \\
\hline Wheat1 & $\mathrm{C}$ & 9.1 & $\begin{array}{l}\text { Oats/ } \\
\text { winter wheat }\end{array}$ & $\begin{array}{l}\text { Synthetic } \\
\text { Slurry (pig) }\end{array}$ & $\begin{array}{l}76 \\
0\end{array}$ & $\begin{array}{l}1 / 4 / 2008 \\
-\end{array}$ & $\begin{array}{l}50+50 \\
87\end{array}$ & $\begin{array}{l}1 / 3 / 2009 ; 1 / 4 / 2009 \\
23 / 4 / 2009\end{array}$ \\
\hline Wheat2 & $\mathrm{C}$ & 11.6 & $\begin{array}{l}\text { Winter wheat/ } \\
\text { winter wheat }\end{array}$ & $\begin{array}{l}\text { Synthetic } \\
\text { Slurry (pig) }\end{array}$ & $\begin{array}{l}72 \\
135\end{array}$ & $\begin{array}{l}5 / 5 / 2008 \\
1 / 4 / 2008\end{array}$ & $\begin{array}{l}72 \\
112\end{array}$ & $\begin{array}{l}5 / 5 / 2009 \\
22 / 4 / 2009\end{array}$ \\
\hline Wetland & $\mathrm{C}$ & 1.0 & $\begin{array}{l}\text { Mixture of } \\
\text { herbs }\end{array}$ & None & 0 & - & 0 & - \\
\hline
\end{tabular}

${ }^{\mathrm{a}} \mathrm{kg}$ total $\mathrm{N}$.

$\mathrm{b}$ Excluding manure excreted by grazing cattle.

with a combination of synthetic fertilizer and animal manure (Wohlfart et al., 2012). The climate of the region, Central Jutland, is coastal temperate with a mean annual precipitation (1961-1990) of $722 \mathrm{~mm}$ and annual mean temperature of $7.7^{\circ} \mathrm{C}$. The mean temperatures of the coldest and warmest months of the year (February and July) are $0.1^{\circ} \mathrm{C}$ and $15.4^{\circ} \mathrm{C}$, respectively. The experiment took place during September 2007-April 2009. During the first full year, measurements focused on three long-term sites (Arable1, Arable2 and Meadow ${ }^{08}$; Table 1 and Fig. 1). In spring 2009, a coordinated effort was made to study more sites during an intensive period (21-28 April 2009). Ahead of the intensive campaign, the long-term sites were pre-monitored, beginning on 30 March 2009. The study took place at sites and fields that were conventionally managed by the farmers of the area. Three different farmers own and managed the fields studied. Agricultural management was recorded through farmer interviews, by consulting agronomic advisory services, and by observations made by the researchers. During the intensive measurement campaign of April 2009, pig slurry was applied to three wheat fields (Wheat1, Wheat2, Wheat3) using trailing hoses, and the days of application were agreed to accommodate the measurement activities. An overview of fields and fertilization rates during 2007-2009 is given in Table 1.

\subsection{Chamber measurements}

Four chamber types, $\mathrm{CH} 1-\mathrm{CH} 4$, were applied for measuring fluxes of $\mathrm{N}_{2} \mathrm{O}$ within the landscape (Table 2). All were twopart static chambers located at the sites shown in Fig. 1. A total of 75 chambers were installed in groups of 5-6 chambers at ten different locations or fields to cover different topography, land use, and crop types. $\mathrm{CH} 2$ chambers were deployed throughout 2007-2009 at monthly or bi-monthly intervals, with a higher frequency in periods of increased management activity, especially fertilization. All chamber types were used during the April 2009 campaign when some chamber types were installed in groups in the same fields (Table 2). For the 2009 campaign, the chamber frames were installed prior to and remained in place during and after slurry application. For the long-term installations in Arable1 and Arable2, the $\mathrm{CH} 2$ steel frames were installed and only removed for harvest and seedbed preparation. On each sampling day and for each chamber, 30-ml (CH1, CH3) or 10-ml (CH2) gas samples were taken at four regular time intervals between 0 and $70 \mathrm{~min}(\mathrm{CH} 1, \mathrm{CH} 3)$ or 0 and $90 \mathrm{~min}(\mathrm{CH} 2)$. Gas sampling from $\mathrm{CH} 4$ was 3 samples made at 15 -min intervals. Samples were stored in pre-evacuated $12.5-\mathrm{ml}$ or $6-\mathrm{ml}$ glass vials in preparation for analysis. $\mathrm{N}_{2} \mathrm{O}$ concentrations in the gas samples were subsequently analysed using gas chromatography at three different laboratories. Samples from $\mathrm{CH} 2$ chambers were analysed according to Petersen et al. (2008) in 2007-2008 and according to Petersen et al. (2011) in 2009. 
Table 2. Chamber types and fields where they were used in the Bjerringbro landscape. C2009 indicates the fields where the chambers were used during the 2009 intensive campaign.

\begin{tabular}{|c|c|c|c|c|c|}
\hline $\begin{array}{l}\text { Chamber } \\
\text { type ID }\end{array}$ & $\begin{array}{l}\text { Chamber } \\
\text { area } \\
\left(\mathrm{m}^{2}\right)\end{array}$ & $\begin{array}{l}\text { Effective } \\
\text { volume } \\
\text { (L) }\end{array}$ & $\begin{array}{l}\text { Number of } \\
\text { chambers }\end{array}$ & Materials and other information & Operated at fields \\
\hline $\mathrm{CH} 1$ & 0.24 & 50 & 39 & $\begin{array}{l}\text { Al-frame \& plastic cover } \\
\text { clamped to frame. No vent, } \\
\text { no mixing. }\end{array}$ & $\begin{array}{l}\text { C2009: Wheat } 1 \text {, Wh1Slope, } \\
\text { Wheat2, Wheat } 3 \text {, Grass, } \\
\text { Wetland, Meadow } 09\end{array}$ \\
\hline $\mathrm{CH} 2$ & 0.21 & $\begin{array}{l}45 \text { or } \\
100\end{array}$ & 16 & $\begin{array}{l}\text { Steel frame with plastic cover } \\
\text { inserted into water-filled rim of } \\
\text { frame. Vented, no mixing. }\end{array}$ & $\begin{array}{l}\text { 2007-8: Arable1, Arable2, } \\
\text { Meadow } 08 \\
\text { C2009: Arable1, } \\
\text { Arable2, Wheat3 }\end{array}$ \\
\hline $\mathrm{CH} 3$ & 0.24 & 65 & 10 & $\begin{array}{l}\text { Plastic frame and plastic cover } \\
\text { inserted into water-filled rim of } \\
\text { frame. No vent, no mixing. }\end{array}$ & C2009: Wheat1, Wheat2 \\
\hline $\mathrm{CH} 4$ & 0.007 & 0.5 & 10 & $\begin{array}{l}\text { Plastic cylinder and plastic } \\
\text { cover. No vent, no mixing. }\end{array}$ & C2009: Wheat2 \\
\hline
\end{tabular}

Samples taken from $\mathrm{CH} 1$ and $\mathrm{CH} 3$ chambers were analysed according to Vilain et al. (2010). Samples taken from CH4 were analysed according to Machon et al. (2010).

$\mathrm{N}_{2} \mathrm{O}$ fluxes were calculated using the HMR procedure (Pedersen et al., 2010), available as an add-on package for the free programming software R (http://www.r-project.org). The HMR tool analyses non-linear concentration time series based on the model by Hutchinson and Mosier (1981). If the concentration data develop linearly with time, a linear regression is applied. HMR suggests the optimal analysis method and offers a graphical interface where the user makes the final decision on analysis method for each concentration time series. HMR calculates statistics for each regression, enabling the rejection of fluxes that are not significantly different from zero. In this study, a concentration dataset of four samples over time was accepted only if it gave a statistically significant regression $(p \leq 0.15)$.

\subsection{Meteorology and soil}

Meteorological records (hourly and daily time resolution) of air temperature, global radiation, and precipitation were obtained for the entire measurement period from a meteorological station operated by the Danish Meteorological Institute and located in a similar agricultural landscape $25 \mathrm{~km}$ east of the area. Daily reference evapotranspiration $\left(E_{\text {ref }}\right)$ was derived from the meteorological data and the Makkink equation (de Bruin and Lablans, 1998). The Makkink equation has been shown to provide adequate evapotranspiration estimates for an unstressed grass crop for Danish conditions (Kjaersgaard et al., 2008), and $E_{\text {ref }}$ was assumed to be close to the potential evapotranspiration of the range of crops and land-use types studied. Soil water content was measured using a portable TDR and a $0.25 \mathrm{~m}$ probe near the chamber lo- cations. Measurement frequency was the same as that of the $\mathrm{N}_{2} \mathrm{O}$ flux measurements, except for some occasions when the TDR probes could not be inserted because the soil was too dry. In addition, during the intensive campaign in 2009 , meteorological variables (radiation, air and soil state variables including soil water content in the topsoil) were measured at field Wheat2 with a high time resolution (15 min) using an instrument setup similar to that described in Horvath et al. (2005) and Meszaros et al. (2009). During the campaign period, a mast equipped with instruments for Bowen ratio measurements (Campbell Scientific, Loughborough, UK) of heat fluxes was also installed at field Wheat2. Throughout the 20-month period of measurements, soil was sampled near chamber positions on a subset of the dates when $\mathrm{N}_{2} \mathrm{O}$ fluxes were measured. On each sampling date, five soil cores were taken from random locations at each site and the samples from the $0-25 \mathrm{~cm}$ and $25-50 \mathrm{~cm}$ soil layers were pooled to obtain representative composite subsamples for the two depths. Samples were kept cool $\left(<10^{\circ} \mathrm{C}\right)$ during transport to the laboratory. Samples were frozen until analysed for $\mathrm{NO}_{3}^{-}$and $\mathrm{NH}_{4}^{+}$content, according to Mutegi (2010) for samples taken near chambers $\mathrm{CH} 2$ and according to Vilain et al. (2010) for samples taken near chambers $\mathrm{CH} 1$ and $\mathrm{CH} 3$.

\section{Results}

\subsection{Meteorology}

Meteorological conditions during the 20-month measurement period (2007-2009) were not unusual. The two winters were mild with occasional frosts. Springs of 2008 and 2009 were both characterised by relatively dry conditions during mid to late April-May. In this rain-fed agricultural landscape 
with sandy loam soils, these conditions caused the soils to dry out. Accordingly, measurements of soil water content at $5 \mathrm{~cm}$ depth of field Wheat 2 during the intensive measurement period (19-29 April 2009) showed a steady decrease in the volumetric water content from $15 \%$ to $10 \%$. Another indicator of soil water depletion and crop water stress was that during 19-28 April 2009 actual evapotranspiration, measured in the same wheat field using the Bowen Ratio method, was $64 \%$ of $E_{\text {ref }}$ that represented a grass surface without water stress. This ratio was calculated as the accumulated latent heat fluxes divided by accumulated daily reference evapotranspiration.

\subsection{Chamber type and flux analysis method}

When considering all significant fluxes recorded during 2007-2009, application of the flexible HMR procedure for analysing chamber $\mathrm{N}_{2} \mathrm{O}$ concentrations resulted in calculated fluxes that were on average $32 \%$ higher than fluxes calculated using a linear regression only (Fig. 2). For the limited period of intensive measurements during 2009, the HMRbased fluxes were $16 \%$ higher than fluxes derived solely from a linear regression. During the intensive period of 2009, more chamber types were applied and some types were located in the same fields (Table 2). There was however no attempt to duplicate chamber measurements, so a day-to-day comparison between chambers types was not possible due to the spatial variability and different sampling schemes. Table 3 presents mean values of measured emissions during the 2009 campaign with the four types of chambers. Fluxes measured at Wheat 3 using two chamber types $(\mathrm{CH} 1, \mathrm{CH} 2)$ were in good agreement before the slurry application. At Wheat2, using another combination of chambers $(\mathrm{CH} 1, \mathrm{CH} 3)$, fluxes were in good agreement both before and after the slurry application. However at Wheat2, chambers $\mathrm{CH} 4$ generally estimated small fluxes that were unaffected by the slurry application, in contrast to the two other chamber types. In field Wheat1, chambers $\mathrm{CH} 3$ generally measured smaller fluxes than chambers $\mathrm{CH} 1$.

\subsection{Spatial variability}

The variability of $\mathrm{N}_{2} \mathrm{O}$ flux measurements made at a specific site using 5-6 chambers was quantified via the coefficient of variation $(\mathrm{CV})$. The $\mathrm{CV}$ of flux estimates was $30-150 \%$ depending on time of year and site, with the only obvious trend indicating higher values for the meadow site in 2007-2008, where CVs were $100-200 \%$. CVs were typically high during periods of relatively low fluxes when some chambers estimated a zero flux, and CVs were typically low when fluxes were high. During the 2009 intensive campaign, CVs, calculated per chamber type and site, ranged between $60 \%$ and $140 \%$. Practically all measured fluxes were positive.

The effect of land use and land management on $\mathrm{N}_{2} \mathrm{O}$ fluxes was studied using the full year of measurements at

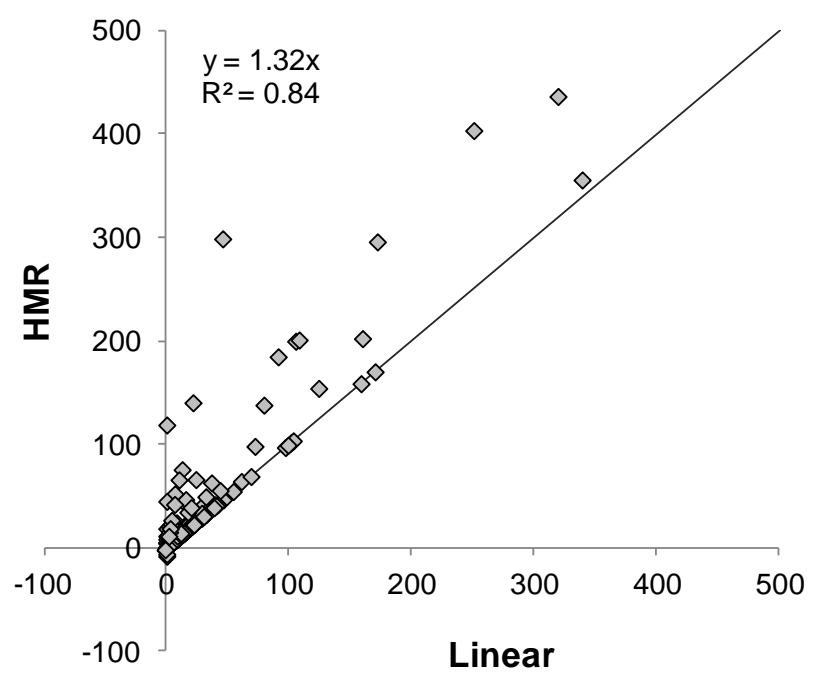

Fig. 2. Calculated $\mathrm{N}_{2} \mathrm{O}$ fluxes (ng N m $\mathrm{m}^{-2} \mathrm{~s}^{-1}$ ), using the HMR tool, versus calculated fluxes using a linear regression for the analysis of chamber concentrations. The figure shows all significant individual chamber fluxes below $500 \mathrm{ng} \mathrm{N} \mathrm{m}^{-2} \mathrm{~s}^{-1} \quad(2007-2009 ; n=364)$. Four individual chamber fluxes were larger than $500 \mathrm{ng} \mathrm{N} \mathrm{m}^{-2} \mathrm{~s}^{-1}$. The line is the 1:1 line; the $R^{2}$ value is for a linear regression forced through the origin: HMR flux $=1.32 \times$ Linear flux. For the limited period of intensive measurements during 2009, the equivalent regression was HMR flux $=1.16 \times$ Linear flux.

sites Arable1, Arable2, and Meadow ${ }^{08}$. Differences in management (Table 1) were mainly due to fertilization since the arable fields received both intensive organic and inorganic fertilizers, while the meadow was occasionally grazed by heifers and lightly fertilized with inorganic fertilizer. Fluxes from the meadow were low at all times during the year 2007-2008 $\left(<20 \mathrm{ng} \mathrm{N} \mathrm{m}^{-2} \mathrm{~s}^{-1}\right)$, while fluxes from the arable fields followed an annual pattern with emission peaks during spring and early autumn of up to $600 \mathrm{ng} \mathrm{N} \mathrm{m}^{-2} \mathrm{~s}^{-1}$ (Fig. 3).

During the intensive campaign of 2009, more types of arable fields were studied in addition to areas with more extensive land use. Table 3 shows that mean $\mathrm{N}_{2} \mathrm{O}$ fluxes were all below $12 \mathrm{ng} \mathrm{N} \mathrm{m}^{-2} \mathrm{~s}^{-1}$. Table 3 allows a comparison of campaign emissions from different sites, with a range of fertilization intensities from unmanaged wetland to wheat and other arable fields that had been intensively fertilized for years. Measured wetland emissions were among the lowest recorded fluxes, but emissions of the fertilized fields were also found to be modest during the period.

The effect of topography and associated soil wetness variability on $\mathrm{N}_{2} \mathrm{O}$ fluxes was investigated during the intensive period of 2009 by installing chambers along a transect (Fig. 1) from a plateau or shoulder (Wheat1) down a gentle slope (Wh1Slope) of the wheat field to the footslope in the small stream valley (Meadow ${ }^{09}$ ). The first two transect points had a similar soil texture with a clay content of 7-8\% and a 
Table 3. Measured $\mathrm{N}_{2} \mathrm{O}$ fluxes (ng N m $\mathrm{s}^{-1}$ ) for chambers used during the intensive campaign in April 2009. Values are means (standard error of the mean in parentheses) for the entire intensive measurement period, or for the periods before and after slurry application to the wheat fields. Fields are defined in Table 1, and chamber types (CH1-CH4) are defined in Table 2.

\begin{tabular}{|c|c|c|c|c|c|}
\hline Site & Period & $\mathrm{CH} 1$ & $\mathrm{CH} 2$ & $\mathrm{CH} 3$ & $\mathrm{CH} 4$ \\
\hline \multirow[t]{3}{*}{ Wheat3 } & Entire & $5.8(1.8)$ & $6.4(1.8)$ & & \\
\hline & Before & $5.8(1.8)$ & $5.8(2.2)$ & & \\
\hline & After & & $9.1(2.6)$ & & \\
\hline \multirow[t]{3}{*}{ Wheat2 } & Entire & $10.2(1.7)$ & & $8.6(2.0)$ & $3.0(0.4)$ \\
\hline & Before & $0.1(0.1)$ & & $0.3(0.3)$ & $3.4(0.9)$ \\
\hline & After & $11.7(1.8)$ & & $11.4(2.3)$ & $2.9(0.5)$ \\
\hline \multirow[t]{3}{*}{ Wheat $1^{\mathrm{TR}}$} & Entire & $8.3(0.8)$ & & $2.5(0.6)$ & \\
\hline & Before & $4.6(1.2)$ & & $0.6(0.6)$ & \\
\hline & After & $9.8(0.8)$ & & $3.6(0.8)$ & \\
\hline \multirow[t]{3}{*}{ Wh1Slope ${ }^{\mathrm{TR}}$} & Entire & $5.5(0.6)$ & & & \\
\hline & Before & $4.0(1.1)$ & & & \\
\hline & After & $6.3(0.7)$ & & & \\
\hline Meadow09_TR & Entire & $9.7(2.3)$ & & & \\
\hline Wetland & Entire & $2.9(0.7)$ & & & \\
\hline Grass & Entire & $2.3(0.6)$ & & & \\
\hline Arable1 & Entire & & $8.7(1.3)$ & & \\
\hline Arable2 & Entire & & $3.3(0.7)$ & & \\
\hline
\end{tabular}

TR Site also located on the sloping transect.

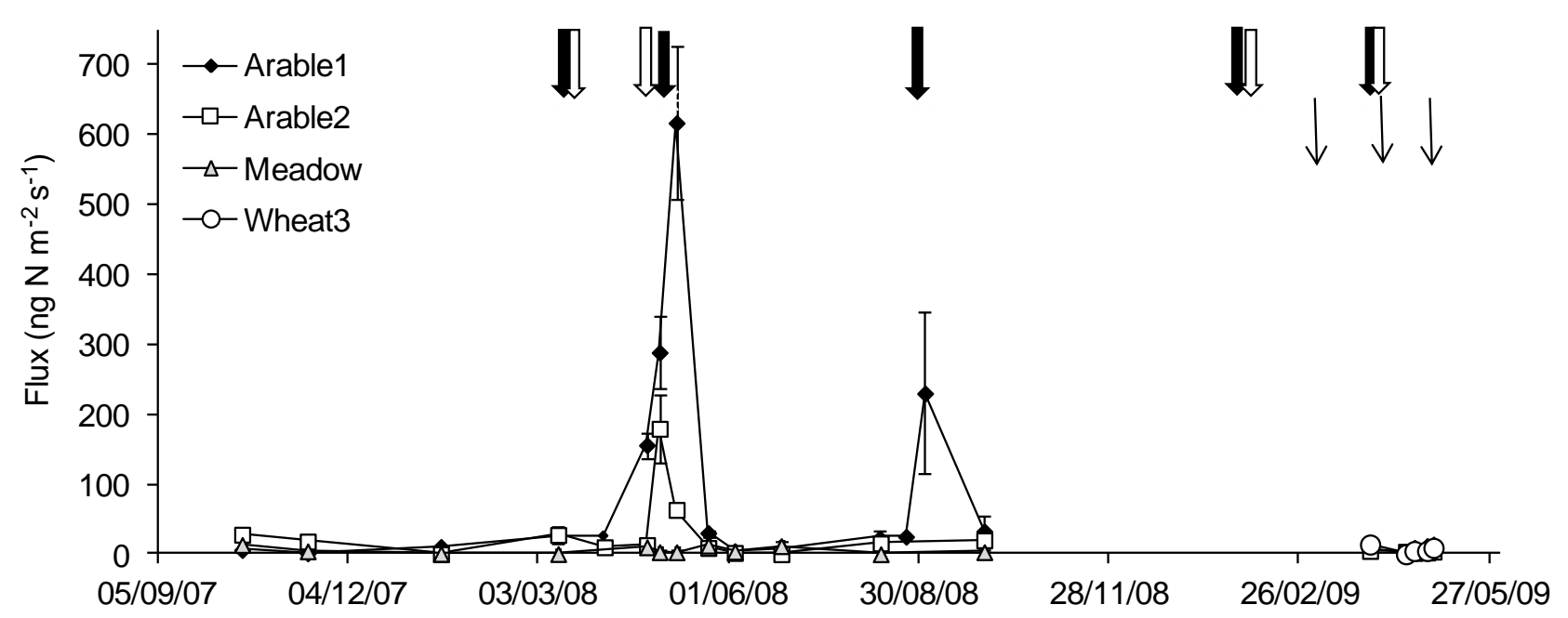

Fig. 3. Measured $\mathrm{N}_{2} \mathrm{O}$ fluxes for the fields with $\mathrm{CH} 2$ type chambers. Error bars show the standard error of the mean. Arrows indicate the timing of fertilizer or manure application: Arable1 (black), Arable2 (white), and Wheat3 (thin arrows). Chambers located at Meadow 08 during 2007-2008 were operated at Wheat3 during the 2009 campaign. Fewer measurements were made at Arable1 due to late sowing of the crop in spring and autumn of 2008; hence, emissions at Arable1 were estimated for a few missing dates.

soil organic matter content of $3 \%$ in $15-30 \mathrm{~cm}$ soil layer. The humus soil in the valley meadow had a larger clay and organic matter content at the $15-30 \mathrm{~cm}$ depth $(16 \%$ and $15 \%$ respectively). The meadow soil was abundant in organic $\mathrm{N}$ (31 and $50 \mathrm{~g} \mathrm{~N} \mathrm{~kg}^{-1}$ DM (dry matter) for the 0-25 and 25$50 \mathrm{~cm}$ soil depths, respectively). In this soil the $\mathrm{C} / \mathrm{N}$ ratio was around 12 for both depths. Soil water content by weight at depth of $5-15 \mathrm{~cm}$ was considerably higher in the valley
(48\%) than in the wheat field $(9 \%)$ on 21 April 2009. On the same date, mineral $\mathrm{N}$ contents were higher in the valley than in the wheat field: $\mathrm{NO}_{3}-\mathrm{N}$ and $\mathrm{NH}_{4}-\mathrm{N}$ concentrations at the wheat field were 4.2 and $4.6 \mathrm{mg} \mathrm{N} \mathrm{kg}^{-1} \mathrm{DM}$, respectively, while $\mathrm{NO}_{3}-\mathrm{N}$ and $\mathrm{NH}_{4}-\mathrm{N}$ concentrations in the valley were 25 and $38 \mathrm{mg} \mathrm{N} \mathrm{kg}^{-1} \mathrm{DM}$, respectively. The recorded $\mathrm{N}_{2} \mathrm{O}$ fluxes along the transect were within the range observed at the other fields during the intensive period of April 2009, 
and, in spite of the different soil conditions, no clear trend in fluxes with respect to position within the transect could be detected, neither in the individual fluxes (data not shown) nor in the mean fluxes (TR; Table 3).

\subsection{Temporal variability}

During the 2009 campaign, fluxes increased when wheat fields were fertilized with pig slurry, with about a doubling of the low emission rates (Table 3 ) although the effect was short-lived (2-3 days; Fig. 4). Since there was no precipitation during the campaign, irrigation (approx. $14 \mathrm{~mm}$ ) was applied at the soil surface within chamber type $\mathrm{CH} 1$ on 26th April 2009. We did not see any clear effect of irrigation on the emissions at any of the irrigated sites (Fig. 4).

Temporal variability was most prominent for the two sites that were continued throughout the 2007-2009 period (Arable1 and Arable2). During April and early May of 2008, both fields experienced high $\mathrm{N}_{2} \mathrm{O}$ emissions with fluxes at Arable1 exceeding $600 \mathrm{ng} \mathrm{N} \mathrm{m}^{-2} \mathrm{~s}^{-1}$ and fluxes at Arable2 exceeding $150 \mathrm{ng} \mathrm{N} \mathrm{m}^{-2} \mathrm{~s}^{-1}$ (Fig. 3). Emissions were low over the summer and increased again in September 2008 at Arable1 when a winter oilseed rape crop had been established. Compared with the fluxes in 2008, all fluxes recorded during spring 2009 were small. Spring peak emissions in 2008 were observed after sowing and fertilization of the crops (Table 1). At Arable2, the highest fluxes were observed after the application of two mineral fertilizer doses and a slurry application. At Arable1, fluxes began to increase significantly after the application of farmyard manure in spring. The autumn emission peak at Arable1 was observed after cultivation and sowing of the winter oilseed rape in late August followed by slurry application on 1 September 2008 (Fig. 3).

\section{Discussion}

\subsection{Chamber methods}

The static chamber method used for investigating the landscape scale variability of nitrous oxide fluxes is a reliable technique that can be deployed in remote areas. Fluxes can also be measured using micrometeorological techniques (Pihlatie et al., 2005) or automated chambers to allow measurements at a much higher temporal resolution (Ambus and Robertson, 1998; Laville et al., 2011), but for the present experiment the static chamber method was applied in order to increase spatial coverage (Theobald et al., 2011). The application of manual static chambers requires great care and is subject to several sources of uncertainty (Livingston and Hutchinson, 1995). The simple static chambers applied in the present experiment would receive a relatively high score according to e.g. dimensions and design, deployment time, number of samples and sample vial type in a systematic evaluation of chambers (Rochette and Eriksen-Hamel, 2008). Only one of the chamber types (CH2) was vented, but

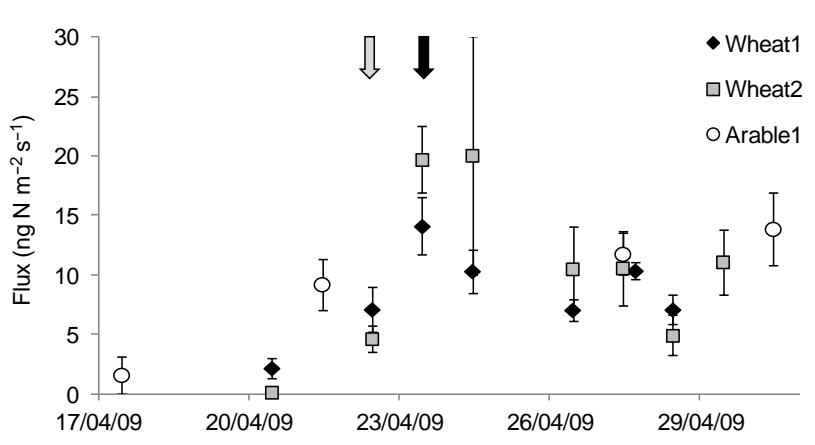

Fig. 4. Measured $\mathrm{N}_{2} \mathrm{O}$ fluxes at two wheat fields and a winter oilseed rape field during the 2009 campaign. Error bars quantify the standard error of the mean. Arrows indicate the timing of slurry application at Wheat 2 followed by Wheat 1 . Flux measurements at the treated fields were made some hours after the slurry application. The oilseed rape (Arable1) was not fertilized during the period. Chambers at both wheat fields were irrigated $(14 \mathrm{~mm})$ on 26 April 2009.

fluxes measured with $\mathrm{CH} 2$ chambers did not appear to differ from other chambers (statistical tests not appropriate due to spatial variability effects). There was an indication that the small $\mathrm{CH} 4$ chambers did not resolve the temporal variability as well as the larger chambers: their average flux did not show any response to slurry application (Table 3). One reason could be that inspection at the Wheat 2 field revealed how slurry was applied, using trailed hoses, into only four of the ten pre-installed 10-cm diameter collars. Hence, these chambers were too small to capture management effects at field scale. Evaluations and protocols on static chamber designs and deployment are emerging (Smith and Conen, 2004; Rochette and Eriksen-Hamel, 2008; Christiansen et al., 2011; Rochette, 2011), and these guidelines should be consulted for future applications of the static chamber method. Also the choice of analysis of the concentration data (linear regression versus non-linear regression types) is important for the resulting fluxes (Anthony et al., 1995; Kutzbach et al., 2007; Venterea 2010). Our findings show that emission estimates were increased by $16-32 \%$ (depending on period taken into account) when using the flexible HMR analysis tool. Kroon et al. (2008) and Thomsen et al. (2010) similarly reported how accounting for non-linearity increased $\mathrm{N}_{2} \mathrm{O}$ flux estimates by approximately $100 \%$ and $25-65 \%$, respectively. Unlike Venterea (2010), who suggested that the theoretical underestimation of linear regression-based fluxes would increase with decreasing soil wetness, our results indicated a smaller underestimation during the dry soil period of 2009 compared with the mean underestimation over the total measurement period (Fig. 2). 


\subsection{Spatial and temporal variability}

Heterogeneity in $\mathrm{N}_{2} \mathrm{O}$ fluxes is expected in natural and managed systems, and the coefficients of variation found in this landscape study (30-200\%) were much in line with the range of variability found in other studies at a similar scale (Ambus and Christensen, 1995; Dunmola et al., 2010; Vilain et al., 2010). Also, site-specific mean emissions may be categorised as being low or high emissions. In the following discussion, we will refer to emissions at a given site and day as being "low" when the measured flux did not exceed $20 \mathrm{ng}$ $\mathrm{N}_{2} \mathrm{O}-\mathrm{N} \mathrm{m}^{-2} \mathrm{~s}^{-1}$. This threshold is close to the one applied by Kavdir et al. (2008).

\subsubsection{Riparian areas}

The lack of topographic effects on $\mathrm{N}_{2} \mathrm{O}$ fluxes, or rather, the finding that emissions were low at all times in the meadow, was somewhat unexpected. Many previous studies have suggested that topography influences $\mathrm{N}_{2} \mathrm{O}$ dynamics, with higher fluxes often found at the footslope compared to fluxes measured on slopes or shoulder positions along a topographical transect (Ambus and Christensen, 1995; Ambus, 1998; Velthof et al., 2000; Vilain et al., 2010). A likely mechanism would be the significant potential for denitrification in the wetter areas where nitrate-rich waters from adjacent agricultural fields converge (Wohlfart et al., 2012). The higher fluxes at the footslope are often associated with the relatively higher water-filled pore space in the soil at the bottom of the slope (Vilain et al., 2010; Gu et al., 2011). By contrast, Dunmola et al. (2010) investigated $\mathrm{N}_{2} \mathrm{O}$ fluxes at upper, middle, lower, and riparian positions of an agricultural landscape and found that the lowest $\mathrm{N}_{2} \mathrm{O}$ emissions were consistently from the uncropped riparian sites. Similarly, Vilain et al. (2010) observed lower fluxes in an unfertilized riparian area compared to a nearby fertilized plot. Within our landscape, gravimetric water content was high in the meadow compared to the slope and shoulder positions of the measurement transect in April 2009. Taking the different soil bulk densities into account, estimated water-filled pore space (WFPS) averaged $50 \%$ in the meadow and $30 \%$ at the slope and shoulder positions under these specific (dry) springtime conditions. Considering soil wetness during the entire period (2007-2009), the groundwater table in the meadow was located just below the soil surface during winter and gradually lowered to approximately $40 \mathrm{~cm}$ below ground during summer. Hence, the relatively wet soil moisture conditions should favour denitrification processes. With respect to substrate availability, $\mathrm{NH}_{4}$ was abundant in the organic meadow soil with respect to $\mathrm{NO}_{3} ; \mathrm{NH}_{4}$ concentrations were $0.020-0.045 \mathrm{~g} \mathrm{NH}_{4}-\mathrm{N} \mathrm{kg}^{-1}$ DM during 2007-2008 with no clear annual trend, and the $\mathrm{NH}_{4} / \mathrm{NO}_{3}$ ratio ranged between 2 and 65 for the $0-25 \mathrm{~cm}$ depth and was equally high for the deeper soil layer. Soil sampled from the top $30 \mathrm{~cm}$ soil layers in April 2009 also confirmed a $\mathrm{NH}_{4} / \mathrm{NO}_{3}$ ratio above 1.0 in the meadow and particularly at the wetland site. In a much more detailed study at a riparian wetland, Hedin et al. (1998) found a pattern in subsurface water chemistry and redox conditions with a dominance of $\mathrm{NO}_{3}$ and $\mathrm{N}_{2} \mathrm{O}$ in the near-stream environment and dominance of $\mathrm{NH}_{4}$ and DOC in the more inland environments. They suggested that $\mathrm{NO}_{3}$ near the stream was due to upwelling of nitrate-rich groundwater, while $\mathrm{NH}_{4}$ abundance further away from the stream was mainly due to mineralisation of soil organic matter. In the inland region, denitrification (and $\mathrm{N}_{2} \mathrm{O}$ production) would be limited by $\mathrm{NO}_{3}$ availability. At our site, some of the adjacent fields and the meadow had tile-drainage (Wohlfart et al., 2012). Therefore, runoff, possibly rich in nitrate, from the adjacent fields may have been primarily directed to the stream via the drains, thus by-passing the meadow to a large extent. If our meadow was dominated by redox conditions similar to those observed by Hedin et al. (1998), this could help explaining why we always saw small $\mathrm{N}_{2} \mathrm{O}$ fluxes from the meadow. However, the measurement setup at the meadow (five flux chambers grouped at Meadow ${ }^{08}$ location during 2007-2008 and five other chambers at Meadow ${ }^{09}$ location during 2009, supplemented by soil sampling for $\mathrm{N}$ content analyses) was insufficient to clarify the water and $\mathrm{N}$ dynamics. A more thorough understanding would require an analysis of the shallow groundwater system, including water sampling in transects along flow lines (Hedin, 1998; Burt, 2005). We conclude, in agreement with Vilain et al. (2010), that $\mathrm{N}_{2} \mathrm{O}$ emissions at riparian buffer areas are highly site-specific and depend on the local hydrology and $\mathrm{N}$ input.

\subsubsection{Arable land}

With the lowest emissions encountered at the meadow and wetland sites, variability in $\mathrm{N}_{2} \mathrm{O}$ emissions was mainly governed by land-use, i.e. fertilized arable fields emitted more $\mathrm{N}_{2} \mathrm{O}$ than the wetland or meadow, which were not, or only marginally, fertilized (Table 1). Within-season management at the field scale was equally important since fluxes were highest after crop establishment and fertilization in spring and autumn (Fig. 3). The importance of land use and management is in agreement with findings of other researchers at field or plot scale. The review by Machefert et al. (2002) revealed that high annual fluxes were predominantly encountered in agricultural ecosystems. Ambus and Christensen (1995) reported that mean annual $\mathrm{N}_{2} \mathrm{O}$ emissions were lowest at five uncropped and unflooded sites, including forest and riparian land, compared with high annual emissions recorded at two arable sites. Chirinda et al. (2010) found that $\mathrm{N}_{2} \mathrm{O}$ emissions were stimulated after spring fertilization in organic and conventional cropping systems. Kavdir et al. (2008) found that the response of $\mathrm{N}_{2} \mathrm{O}$ emission to fertilization and crop type varied differently, calling for a separate interpretation of the results for each crop and fertilization level. In their study, $\mathrm{N}$ fertilization together with annual cropping doubled the $\mathrm{N}_{2} \mathrm{O}$ emissions compared with perennial 
crops. Some of these effects are likely to be linked to cropspecific effects of tillage and (cover) crop residue management (Chatskikh et al., 2008; Petersen et al., 2011). As discussed in Sect. 4.3, the prevailing soil moisture conditions are also important drivers of the temporal variability of $\mathrm{N}_{2} \mathrm{O}$ emissions.

The highest emissions during the experimental period were found at Arable1 and Arable2. The peak emissions recorded at Arable2 in 2008 (up to $180 \mathrm{ng} \mathrm{N} \mathrm{m}^{-2} \mathrm{~s}^{-1}$; Fig. 3) were comparable to other high values measured in arable systems (Hénault et al., 1998; Laville et al., 2011; Petersen et al., 2011) but were higher than maximum fluxes measured by Chirinda et al. (2010, $21 \mathrm{ng} \mathrm{N} \mathrm{m}^{-2} \mathrm{~s}^{-1}$ ) and Mutegi et al. (2010, $14 \mathrm{ng} \mathrm{N} \mathrm{m}^{-2} \mathrm{~s}^{-1}$ ) during the 2008 spring season at cereal crop sites located close $(20 \mathrm{~km})$ to the Bjerringbro landscape. Also during the 2008 spring season, Thomsen et al. (2010) observed maximum emissions of $50 \mathrm{ng} \mathrm{N} \mathrm{m}^{-2} \mathrm{~s}^{-1}$ for cereal field plots on a loamy sand, treated with digested pig slurry, at a site located $55 \mathrm{~km}$ from the Bjerringbro landscape. By contrast, maximum measured emissions at Arable1 during spring and autumn of 2008 (156-617 $\mathrm{ng} \mathrm{N} \mathrm{m}^{-2} \mathrm{~s}^{-1}$, Fig. 3) seemed to be extraordinarily high, although Kroon et al. (2008) observed large fluxes after fertilizer application at an intensively managed grassland and Denmead et al. (2010) found large and sustained emissions $\left(460 \mathrm{ng} \mathrm{N} \mathrm{m}^{-2} \mathrm{~s}^{-1}\right)$ at a fertilized acid sulphate soil producing sugarcane. The spring barley at Arable1 was fertilized with cattle farmyard manure (FYM) and mineral fertilizer in spring 2008, and manure was applied again before sowing the following oilseed rape crop in September 2008 (Table 1). This field had been exposed to many years of manure application, leading to an accumulation of labile organic matter pools. When applying FYM and incorporating it into the soil by ploughing, typically within a few hours to minimize $\mathrm{NH}_{3}$ emissions, the manure can be unevenly distributed on the soil surface (Hansen, 2004), and later in the topsoil. Lumps of farmyard manure, rich in nitrogen and carbon, will exist that have a relatively high local water retention capacity, a high soluble carbon supply and a high $\mathrm{O}_{2}$ demand, leading to the creation of anaerobic microsites that favour denitrification (Petersen and Sommer, 2011) and, therefore, have a high potential for $\mathrm{N}_{2} \mathrm{O}$ emissions. Due to the high water holding capacity of the manure lumps, these conditions may prevail even when the soil is only moderately moist. In contrast, dissolved C and $\mathrm{N}$ in organic slurries with a much lower DM content are more homogenously dispersed into a larger soil volume, thus changing the balance between aerobic and anaerobic decomposition. We hypothesise that heterogeneously incorporated FYM at Arable1 caused the unusually large $\mathrm{N}_{2} \mathrm{O}$ emissions and suggest that the effects of FYM pockets acting as hotspots need further study. Thorman et al. (2007) applied pig and cattle FYM to cereal stubble and bare soil, respectively, with and without incorporation by ploughing. They found peak emissions from the ploughed pig FYM treatments to be up to 20 times larger than those from the equivalent surface applied treatments, while there was no discernible difference in peak emissions between treatments with cattle slurry. On the other hand, Webb et al. (2004) did not find significant losses of $\mathrm{N}_{2} \mathrm{O}$ when cattle or pig FYM was incorporated into the soil. Both Thorman et al. (2007) and Webb et al. (2004) used small chambers with a surface area smaller than $0.03 \mathrm{~m}^{2}$. There seems to be a lack of studies, at field level, of $\mathrm{N}_{2} \mathrm{O}$ emissions following incorporation of FYM or deep litter into soil, using larger chambers or more integrative techniques such as eddy covariance that may take into account the effects of the spatial heterogeneity in FYM incorporation.

\subsection{Fluxes and soil environmental conditions}

As found in several other studies, $\mathrm{N}_{2} \mathrm{O}$ fluxes were influenced by soil inorganic $\mathrm{N}$ content that varied throughout the growing season. $\mathrm{N}_{2} \mathrm{O}$ emission rates, which peaked in spring and autumn 2008 after fertilization, were positively correlated with soil mineral $\mathrm{N}$ content when disregarding times of the year when soil conditions were unfavourable for $\mathrm{N}_{2} \mathrm{O}$ production. In Fig. 5, dry soil conditions (as defined in Fig. 6) are highlighted as conditions when no clear response to mineral $\mathrm{N}$ content would be expected in the recorded $\mathrm{N}_{2} \mathrm{O}$ flux. The relations shown in Fig. 5 for $\mathrm{NO}_{3}$ content in the topsoil, and for total $\mathrm{N}$ content in the topsoil and at a depth of $25-50 \mathrm{~cm}$, exhibit considerable scatter, but still indicate that the lowest emissions occurred when mineral $\mathrm{N}$ concentrations were below approximately $0.01 \mathrm{~g} \mathrm{~N} \mathrm{~kg}^{-1} \mathrm{DM}$. As indicated in Fig. 5, soil moisture conditions influenced $\mathrm{N}_{2} \mathrm{O}$ fluxes. Low soil moisture conditions that prevailed during spring of 2008 and 2009 were poorly represented by the TDR-based recordings of soil moisture (data not shown), since installation of the portable TDR probe into the dry soils was increasingly difficult and eventually impossible. Therefore, we illustrate the soil water conditions in the landscape using a running water budget (Fig. 6), calculated for each day as the accumulated precipitation during the previous 7 days minus the accumulated $E_{\text {ref }}$ during the same period. A water budget of $0 \mathrm{~mm}$ on a given day would indicate balanced precipitation and evapotranspiration during the last 7 days. A threshold of $-16 \mathrm{~mm}$ in the running water budget, equivalent to about 4 days of evapotranspiration without any precipitation, was assumed to be a limit defining the onset of dry soil conditions, primarily in the topsoil from where water would be evaporated first. Figure 6 (top) shows that springtime accumulated $E_{\text {ref }}$ exceeded incoming precipitation from mid-April during both 2008 and 2009. During the intensive campaign of late April 2009, dry soil conditions prevailed. This was also temporarily the case during the equivalent period of 2008 , whereas soil water content was higher in early April and much of May 2008. The timing of the dry and wet periods coincided closely with observed $\mathrm{N}_{2} \mathrm{O}$ fluxes during the spring seasons of the two years. Hence, the unexpectedly low fluxes that were observed in 2009 were presumably caused by the 

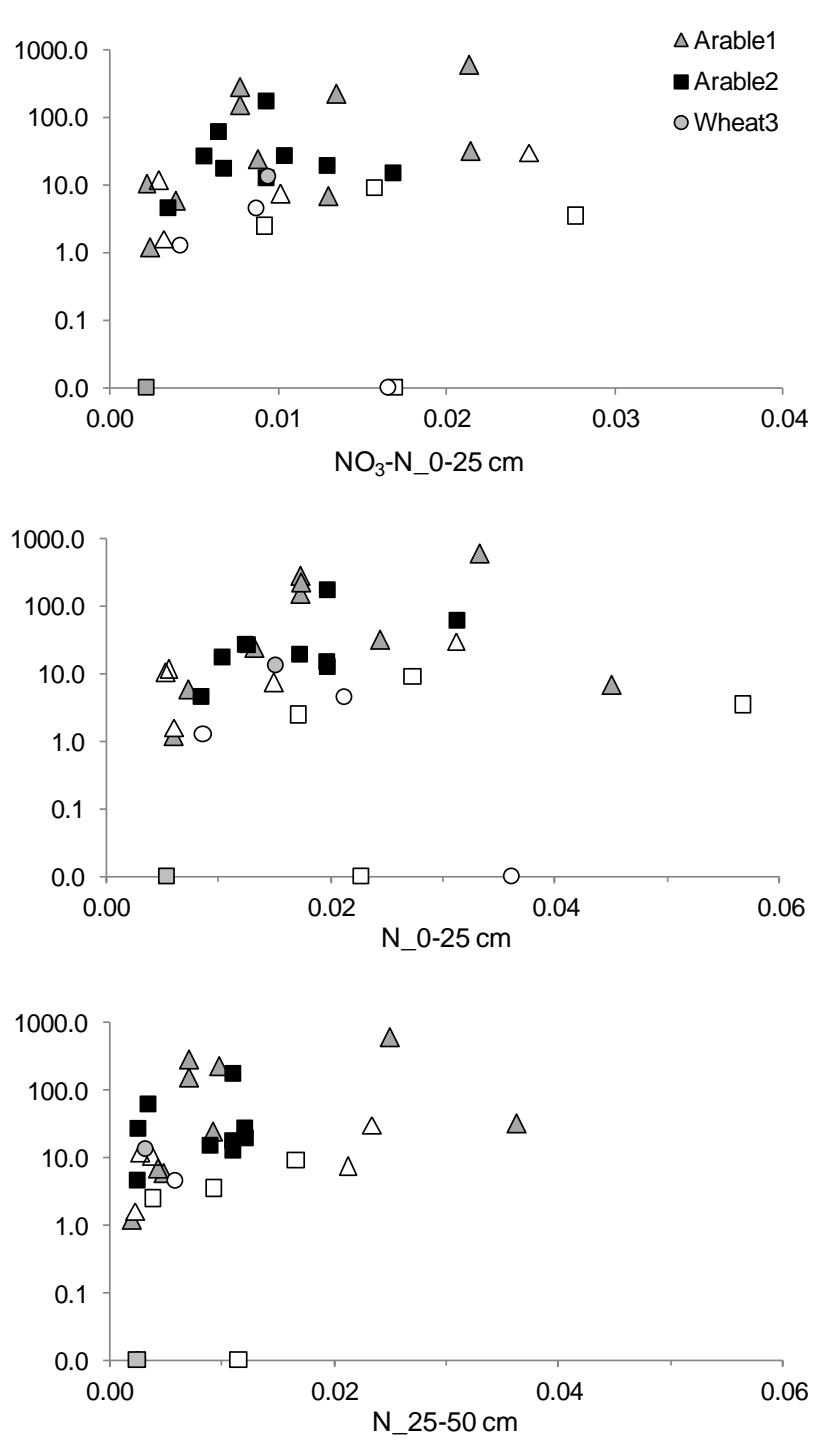

Fig. 5. $\mathrm{N}_{2} \mathrm{O}$ fluxes $\left(\right.$ ng N m $\mathrm{N}^{-2} \mathrm{~s}^{-1}$ ) versus soil $\mathrm{NO}_{3}-\mathrm{N}$ or total mineral $\mathrm{N}$ content $\left(\mathrm{g} \mathrm{N} \mathrm{kg}^{-1} \mathrm{DM}\right)$ for the $0-25 \mathrm{~cm}$ and $25-50 \mathrm{~cm}$ soil layers. Data are from 2008-2009 for three arable sites with $\mathrm{CH} 2$ type chambers. Open symbols represent measurements when soil conditions were "dry" (running water balance $<-16 \mathrm{~mm}$; see Fig. 6).

dry soil conditions. The amount of liquid supplied with the slurry was no more than $2.0-2.5 \mathrm{~mm}$, hence barely contributing to re-wet the topsoil. Nor was the small-scale irrigation of $\mathrm{CH} 1 \mathrm{chambers}(14 \mathrm{~mm})$ enough to counteract the soil water deficit of $20 \mathrm{~mm}$ on 26 April 2009 (Fig. 6). By contrast, high fluxes in late April and May 2008 were observed after re-wetting of the soil by $32 \mathrm{~mm}$ of rainfall to reach a positive soil water balance. When soil is re-wetted after a dry period, a pulse of $\mathrm{N}_{2} \mathrm{O}$ has been observed by several authors due to increased nutrient availability for microbes (Mummey et al., 1994; Zebarth et al., 2008; Chirinda et al., 2010). Soil water

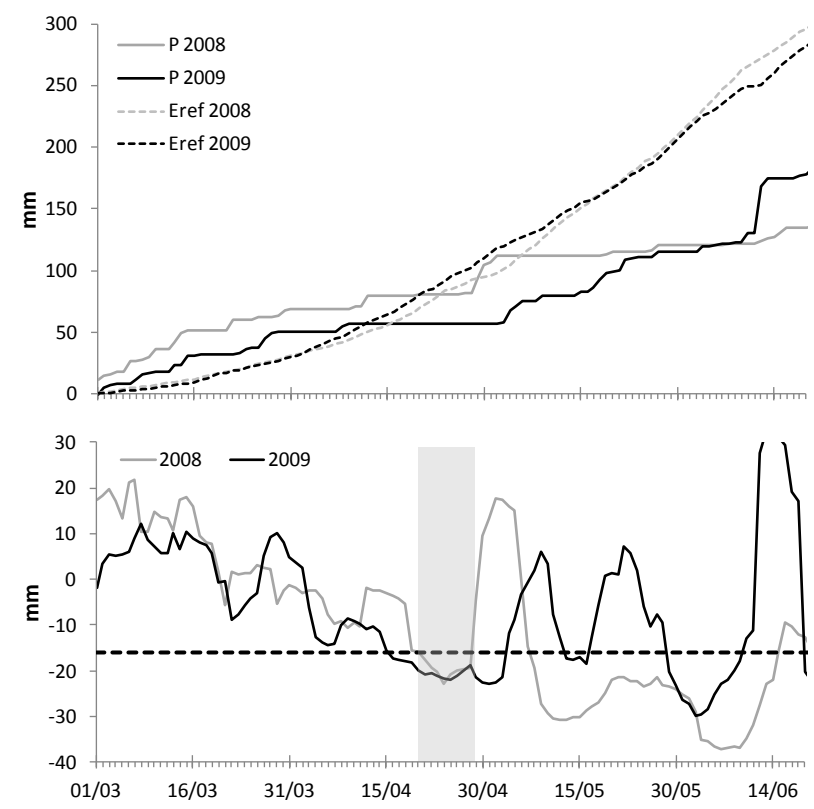

Fig. 6. Top: accumulated precipitation $(P)$ and reference evapotranspiration $\left(E_{\text {ref }}\right)$ during March-June of 2008 and 2009. Bottom: running 7-d water budget ( $\left.\Sigma P-\Sigma E_{\text {ref }}\right)$ during March-June of 2008 and 2009. The timing of the 2009 intensive campaign is indicated by the shaded area. A water budget threshold has been indicated at $-16 \mathrm{~mm}$ to identify periods of "dry soil conditions" when the running budget was below the threshold.

content influences $\mathrm{N}_{2} \mathrm{O}$ emission from all types of soil. In general, aerobic microbial activity peaks at an intermediate water content and it has been reported that nitrification and associated $\mathrm{N}_{2} \mathrm{O}$ production peak at around $60 \%$ water-filled pore space or higher (Schjønning et al., 2011), while optimum conditions for denitrification may occur at up to 60$90 \%$ water-filled pore space (Linn and Doran, 1984; Hénault et al., 2005).

\subsection{Annual nitrous oxide emissions}

The emissions recorded at Arable1, Arable2, and Meadow 08 during the year from 15 October 2007 to 15 October 2008 were accumulated to give annual emissions (Table 4). The accumulation was done by linear interpolation of fluxes during periods of frequent measurements. For periods with more infrequent sampling, the environmental and management conditions prevailing at the time of a gap were considered: Fewer measurements were made at Arable1 due to late sowing of the crop in spring and autumn of 2008, leading to delayed re-installation of chamber frames. For the calculation of annual emissions, flux values for three missing dates in March and late August 2008 at Arable1 were estimated to remain at a low value (measured before the time gap) until the time of sowing and fertilization (Fig. 3). The estimated annual emission at the meadow $\left(1.2 \mathrm{~kg} \mathrm{~N}_{2} \mathrm{O}-\mathrm{N} \mathrm{ha}^{-1} \mathrm{yr}^{-1}\right)$ 
Table 4. Accumulated $\mathrm{N}_{2} \mathrm{O}$ fluxes during the year from 15 October 2007 to 15 October 2008 at three sites equipped with $\mathrm{CH} 2$ chambers. For the calculation of annual emissions, emission values for three missing dates at Arable1 were estimated to remain low until the time of sowing and fertilization. $\mathrm{N}$-input is the direct fertilizer and manure $\mathrm{N}$ addition during the one-year period.

\begin{tabular}{|c|c|c|c|}
\hline $\mathrm{N}_{2} \mathrm{O}$ flux unit & Arable1 & Arable2 & Meadow $^{08}$ \\
\hline $\mathrm{kg} \mathrm{N}_{2} \mathrm{O}-\mathrm{N} \mathrm{ha} \mathrm{yr}^{-1}$ & 17.5 & 5.5 & 1.2 \\
\hline Emission/N-input (\%) & 7.7 & 2.5 & $2.4^{*}$ \\
\hline
\end{tabular}

* Excluding manure excreted by grazing heifers.

was comparable to fluxes measured in equivalent systems $\left(0.66 \mathrm{~kg} \mathrm{Nha}^{-1} \mathrm{yr}^{-1}\right.$, Ambus and Christensen, 1995; and $2-4 \mathrm{~kg} \mathrm{Nha}^{-1} \mathrm{yr}^{-1}$, Hefting et al., 2003). The estimated annual fluxes at Arable1 (17.5 $\mathrm{kg} \mathrm{N}_{2} \mathrm{O}-\mathrm{N} \mathrm{ha}^{-1} \mathrm{yr}^{-1}$ ) and Arable2 (5.5 $\mathrm{kg} \mathrm{N}_{2} \mathrm{O}-\mathrm{N} \mathrm{ha}^{-1} \mathrm{yr}^{-1}$ ) were larger than annual emission estimates in conventional arable cropping systems $\left(0.9 \mathrm{~kg} \mathrm{Nha}^{-1} \mathrm{yr}^{-1}\right.$, Chirinda et al., 2010; 1.7$2.9 \mathrm{~kg} \mathrm{~N} \mathrm{ha}^{-1} \mathrm{yr}^{-1}$, Laville et al., $2011 ; 1-3 \mathrm{~kg} \mathrm{~N} \mathrm{ha}^{-1} \mathrm{yr}^{-1}$, Kavdir et al., 2008). The reported annual estimates from the literature were generally obtained under controlled research grade experimental conditions, while the present results reflect the management, in terms of timing and historical fertilizer application rates, of a commercial Danish farmer. Kroon et al. (2008) also found large cumulative $\mathrm{N}_{2} \mathrm{O}-\mathrm{N}$ fluxes on a commercial dairy farm, and Denmead et al. (2010) measured large cumulative emissions at a commercial sugar cane farm. The differences between our results and the majority of results from the literature continue to be evident when comparing annual $\mathrm{N}_{2} \mathrm{O}-\mathrm{N}$ emissions as fractions of the recent $\mathrm{N}$ input to the crop growing cycle (Table 4). Our losses of 2.5-7 \% of annual fertilizer and manure $\mathrm{N}$ input were high compared to many systems examined in the literature $(0.5 \%$, Chirinda et al., 2010; 1.1-1.9\%, Laville et al., 2011; 0.7$2.4 \%$, Kavdir et al., 2008), and higher than the IPCC default $\mathrm{N}_{2} \mathrm{O}$ emission factor of $1 \%$ of $\mathrm{N}$ applied (IPCC, 2006). However, the emissions observed at our sites were gross fluxes influenced by historical $\mathrm{N}$ inputs and residue management and therefore not only attributable to the most recent $\mathrm{N}$ additions. Within agricultural systems, there can be substantial background $\mathrm{N}_{2} \mathrm{O}$ emissions as demonstrated when $\mathrm{N}$-application is omitted (Kavdir et al., 2008; Petersen et al., 2006).

\section{Conclusions and implications for modelling}

Our calculations of $\mathrm{N}_{2} \mathrm{O}$ emissions from an agricultural landscape confirmed the influence of using non-linear regression vs. linear regression on the inherent flux underestimation with static chamber techniques. Rather than simple spreadsheet solutions for flux calculations, we recommend applying a non-linear regression tool that is neither complicated nor ambiguous, such as the freely available HMR software.
Estimated annual emissions of nitrous oxide from two arable fields (Arable1 and Arable2) that had been fertilized with mineral fertilizer and manure were large (17 $\mathrm{kg} \mathrm{Nha}^{-1} \mathrm{yr}^{-1}$ and $5.5 \mathrm{~kg} \mathrm{Nha}^{-1} \mathrm{yr}^{-1}$, respectively) during a year when soil water conditions were favourable for $\mathrm{N}_{2} \mathrm{O}$ production during the first month following fertilizer application in spring. Peak emissions during that first year reached $200-600 \mathrm{ng} \mathrm{N} \mathrm{m}^{-2} \mathrm{~s}^{-1}$, with the largest emissions occurring after spring fertilization. By contrast, emissions were found to be consistently and relatively low $\left(<20 \mathrm{ng} \mathrm{N} \mathrm{m}^{-2} \mathrm{~s}^{-1}\right)$ at a range of land use types when monitored during two weeks of the spring/fertilization period of the following year. The latter period coincided with dry soil conditions, and the modest fluxes recorded, even after slurry application, were attributed to these dry environmental conditions. Consequently, the intensive monitoring period failed to demonstrate clear trends in $\mathrm{N}_{2} \mathrm{O}$ emissions as a function of position in the landscape, either topographical or according to land use type.

Models of organic matter turnover and microbial activity in arable soils use different empirical relationships for describing the effects of soil temperature and soil moisture conditions (Rodrigo et al., 1997; Bauer et al., 2008). The findings in our landscape that the environmental conditions and soil dryness controlled or limited $\mathrm{N}_{2} \mathrm{O}$ emissions confirm the importance of the water response function for modelling.

Generally, models may have difficulties in capturing responses or effects of different fertilizer inputs on $\mathrm{N}_{2} \mathrm{O}$ emissions (Frolking et al., 1998; Chatskikh et al., 2008). Modelling emissions of $\mathrm{N}_{2} \mathrm{O}$ from field applied with manure, especially farmyard manure, is a particular challenge due to the heterogeneity in the distribution of $\mathrm{O}_{2}$ supply and demand within the soil. Within the Bjerringbro landscape, we found large $\mathrm{N}_{2} \mathrm{O}$ emissions from an arable field after the application and incorporation of farmyard manure and attributed the $\mathrm{N}_{2} \mathrm{O}$ losses to lumps of manure acting as hotspots within the field soil. These emissions may be difficult to predict using even the best available models (Chen et al., 2008; Farquharson and Baldock, 2008).

Acknowledgements. This research was funded by the European Commission (NitroEurope Integrated Project, Contract 017841.00 of the EU Sixth Framework Programme for Research and Technological Development) and the Danish Ministry for Food and Agriculture. The authors would also like to thank COST Action 729 and the ESF-NinE programme for co-funding the joint measurement campaign and a workshop at the Bjerringbro landscape during April 2009. Thanks are also due to COST Action ES 0804 and the TÁMOP 4.2.1./B-09/1/KMR-2010-0003. We thank J. Bienkowski, K. Janku, A. Pogány, A. Bordás, B. Durand, and A. Cobena for assisting in the field during the intensive campaign. Finally, we thank the three local farmers at Bjerringbro for letting us access and make measurements on their fields and for allowing us to decide the exact days of slurry application during April 2009.

Edited by: S. Reis 


\section{References}

Ambus, P.: Nitrous oxide production by denitrification and nitrification in temperate forest, grassland and agricultural soils, Eur. J. Soil Sci., 49, 495-502, 1998.

Ambus, P. and Christensen, S.: Spatial and seasonal nitrous oxide and methane fluxes in Danish forest-, grassland-, and agroecosystems, J. Environ. Qual., 24, 993-1001, 1995.

Ambus, P. and Robertson, G. P.: Automated near-continuous measurement of carbon dioxide and nitrous oxide fluxes from soil, Soil Sci. Soc. Am. J., 62, 394-400, 1998.

Anthony, W. H., Hutchinson, G. L., and Livingston, G. P.: Chamber measurement of soil-atmosphere gas exchange - linear vs diffusion-based flux models, Soil Sci. Soc. Am. J., 59, 13081310, 1995.

Bauer, J., Herbst, M., Huisman, J. A., Weihermüller, L., and Vereecken, H.: Sensitivity of simulated soil heterotrophic respiration to temperature and moisture reduction functions, Geoderma, 145, 17-27, 2008.

Burt, T. P.: A third paradox in catchment hydrology and biogeochemistry: decoupling in the riparian zone, Hydrol. Proc., 19, 2087-2089, 2005.

Chatskikh, D., Olesen, J. E., Berntsen, J., Regina, K., and Yamulki, S.: Simulation of effect of soils, climate and management on $\mathrm{N}_{2} \mathrm{O}$ emission from grassland, Biogeochemistry, 76, 395-419, 2005.

Chatskikh, D., Olesen, J. E., Hansen, E. M., Elsgaard, L., and Petersen, B. M.: Effects of reduced tillage on net greenhouse gas fluxes from loamy sand soil under winter crops in Denmark, Agric. Ecosyst. Environ., 128, 117-126, 2008.

Chirinda, N., Carter, M. S., Albert, K. R., Ambus, P., Olesen, J. E., Porter, J. R., and Petersen, S. O.: Emissions of nitrous oxide from arable organic and conventional cropping systems on two soil types, Agric. Ecosyst. Environ., 136, 199-208, 2010.

Christiansen, J. R., Korhonen, J. F. J., Juszczak, R., Giebels, M., and Pihlatie, M.: Assessing the effects of chamber placement, manual sampling and headspace mixing in $\mathrm{CH}_{4}$ fluxes in a laboratory experiment, Plant Soil, 343, 171-185, 2011.

Chatskikh, D., Olesen, J., Berntsen, J., Regina, K., and Yamulki, S.: Simulation of effects of soils, climate and management on $\mathrm{N}_{2} \mathrm{O}$ emission from grasslands, Biogeochemistry, 76, 395-419, 2005.

Chatskikh, D., Olesen, J. E., Hansen, E. M., Elsgaard, L., and Petersen, B. M.: Effects of reduced tillage on net greenhouse gas fluxes from loamy sand soil under winter crops in Denmark, Agric. Ecosyst. Environ., 128, 117-126, 2008.

Chen, D., Li, Y., Grace, P., and Mosier, A. R.: $\mathrm{N}_{2} \mathrm{O}$ emissions from agricultural lands: a synthesis of simulation approaches, Plant Soil, 309, 169-189, 2008.

Dalgaard, T., Heidmann, T., and Mogensen, L.: Potential N-losses in three scenarios for conversion to organic farming in a local area in Denmark, Eur. J. Agron., 16, 207-217, 2002.

De Bruin, H. A. R. and Lablans, W. N.: Reference crop evapotranspiration determined with a modified Makkink equation, Hydrol. Proc., 12, 1053-1062, 1998.

Denmead, O. T., Macdonald, B. C. T., Bryant, G., Naylor, T., Wilson, S., Griffith, D. W. T., Wang, W. J., Salter, B., White, I., and Moody, P. W.: Emissions of methane and nitrous oxide from Australian sugarcane soils, Agr. Forest Meteorol., 150, 748-756, 2010 .
Dunmola, A. S., Tenuta, M., Moulin, A. P., Yapa, P., and Lobb, D. A.: Pattern of greenhouse gas emission from a Prairie Pothole agricultural landscape in Manitoba, Canada, Can. J. Soil Sci., 90, 243-256, 2010.

Duretz, S., Drouet, J. L., Durand, P., Hutchings, N. J., Theobald, M. R., Salmon-Monviola, J., Dragosits, U., Maury, O., Sutton, M. A., and Cellier, P.: NitroScape: A model to integrate nitrogen transfers and transformations in rural landscapes, Environ. Poll., 159, 3162-3170, 2011.

Farquharson, R. and Baldock, J.: Concepts in modelling $\mathrm{N}_{2} \mathrm{O}$ emissions from land use, Plant Soil, 309, 147-167, 2008.

Flechard, C. R., Ambus, P., Skiba, U., Rees, R. M., Hensen, A., van Amstel, A., Pol-van Dasselar, A. V., Soussana, J. F., Jones, M., Clifton-Brown, J., Raschi, A., Horvath, L., Neftel, A., Jocher, M., Ammann, C., Leifeld, J., Fuhrer, J., Calanca, P., Thalman, E., Pilegaard, K., Di Marco, C., Campbell, C., Nemitz, E., Hargreaves, K. J., Levy, P. E., Ball, B. C., Jones, S. K., van de Bulk, W. C. M., Groot, T., Blom, M., Domingues, R., Kasper, G., Allard, V., Ceschia, E., Cellier, P., Laville, P., Henault, C., Bizouard, F. Abdalla, M., Williams, M., Baronti, S., Beretti, F., and Grosz, B.: Effects of climate and management intensity on nitrous oxide emissions in grassland systems across Europe, Agric. Ecosyst. Environ., 121, 135-152, 2007.

Frolking, S. E., Mosier, A. R., Ojima, D. S., Li, C., Parton, W. J., Potter, C. S., Priesack, E., Stenger, R., Haberbosch, C., Dörsch, P., Flessa, H., and Smith, K. A.: Comparison of $\mathrm{N}_{2} \mathrm{O}$ emissions from soils at three temperate agricultural sites: simulations of year-round measurements by four models, Nutr. Cycl. Agroecosyst., 52, 77-105, 1998.

Gu, J., Nicoullaud, B., Rochette, P., Pennock, D. J., Hénault, C., Cellier, P., and Richard, G.: Effect of topography on nitrous oxide emissions from winter wheat fields in Central France, Environ. Poll., 159, 3149-3155, 2011.

Hansen, M. N.: Influence of storage of deep litter manure on ammonia loss and uniformity of mass and nutrient distribution following land spreading, Biosyst. Eng., 87, 99-107, 2004.

Hedin, L. O., von Fisher, J. C, Ostrom, N. E, Kennedy, B. P, Brown, M. G., and Robertson, G. P.: Thermodynamic constraints in nitrogen transformation and other biogeochemical processes at soil-stream interfaces, Ecology, 79, 684-703, 1998.

Hefting, M. M., Bobbink, R., and de Caluwe, H.: Nitrous oxide emission and denitrification in chronically nitrate-loaded riparian buffer zones, J. Environ. Qual., 32, 1194-1203, 2003.

Hénault, C., Devis, X., Page, S., Justes, E., Reau, R., and Germon, J. C.: Nitrous oxide emission under different soil and land management conditions, Biol. Fertil. Soils, 26, 199-207, 1998.

Hénault, C., Bizouard, F., Laville, P., Gabrielle, P., Nicoullaud, B., Germon, J. C., and Cellier, P.: Predicting in situ soil $\mathrm{N}_{2} \mathrm{O}$ emission using NOE algorithm and soil database, Global Change Biol., 11, 115-127, 2005.

Horváth, L., Asztalos, M., Führer, E., Mészáros, R., and Weidinger, T.: Measurement of ammonia exchange over grassland in the Hungarian Great Plain, Agric. Forest Meteorol., 130, 282-298, 2005.

Hutchinson, G. L. and Mosier, A. R.: Improved soil cover method for field measurement of nitrous oxide fluxes, Soil Sci. Soc. Am. J., 45, 311-316, 1981.

IPCC: 2006 IPCC Guidelines for National Greenhouse Gas Inventories, vol. 4, Agriculture, forestry and other land use, Na- 
tional greenhouse gas inventories programme, edited by: Eggleston, H. S., Buendia, L., Miwa, K., Ngara, T., and Tanabe, K., IPCC/IGES, Japan, 2006.

Kavdir, Y., Hellebrand, H. J., and Kern, J.: Seasonal variations of nitrous oxide emission in relation to nitrogen fertilization and energy crop types in sandy soil, Soil \& Tillage Res., 98, 175186, 2008.

Kesik, M., Ambus, P., Baritz, R., Brüggemann, N., ButterbachBahl, K., Damm, M., Duyzer, J., Horváth, L., Kiese, R., Kitzler, B., Leip, A., Li, C., Pihlatie, M., Pilegaard, K., Seufert, S., Simpson, D., Skiba, U., Smiatek, G., Vesala, T., and ZechmeisterBoltenstern, S.: Inventories of $\mathrm{N}_{2} \mathrm{O}$ and $\mathrm{NO}$ emissions from $\mathrm{Eu}-$ ropean forest soils, Biogeosciences, 2, 353-375, doi:10.5194/bg2-353-2005, 2005.

Kjaersgaard, J. H., Plauborg, F., Mollerup, M., Petersen, C. T., and Hansen, S.: Crop coefficients for winter wheat in a sub-humid climate regime, Agric. Water Man., 95, 918-924, 2008.

Kroon, P. S., Hensen, A., Bulk, W. C. M. v. d., Jongejan, P. A. C., and Vermeulen, A. T.: The importance of reducing the systematic error due to non-linearity in $\mathrm{N}_{2} \mathrm{O}$ flux measurements by static chambers, Nutr. Cycl. Agroecosys., 82, 175-186, 2008.

Kutzbach, L., Schneider, J., Sachs, T., Giebels, M., Nykänen, H., Shurpali, N. J., Martikainen, P. J., Alm, J., and Wilmking, M.: $\mathrm{CO}_{2}$ flux determination by closed-chamber methods can be seriously biased by inappropriate application of linear regression, Biogeosciences, 4, 1005-1025, doi:10.5194/bg4-1005-2007, 2007.

Laville, P., Lehuger, S., Loubert, B., Chaumartin, F., and Cellier, P.: Effect of management, climate and soil conditions on $\mathrm{N}_{2} \mathrm{O}$ and $\mathrm{NO}$ emissions from an arable crop rotation using high temporal resolution measurements, Agr. Forest Meteorol., 151, 228-240, 2011.

Linn, D. M. and Doran, J. W.: Effect of water-filled pore space on carbon dioxide and nitrous oxide production in tilled and nontilled soils, Soil Sci. Soc. Am. J., 48, 1267-1272, 1984.

Livingston, G. P. and Hutchinson, G. L.: Enclosure-based measurement of trace gas exchange: applications and sources of error, in: Methods in Ecology, Biogenic Trace Gases: Measuring Emissions from Soil and Water, edited by: Matson, P. A. and Harriss, R. C., Blackwell Sci. Ltd., UK, 15-51, 1995.

Machefert, S. E., Dise, N. B., Goulding, K. W. T., and Whitehead, P.G.: Nitrous oxide emission from a range of land uses across Europe, Hydrol. Earth Syst. Sci., 6, 325-338, doi:10.5194/hess6-325-2002, 2002.

Machon, A., Horváth, L, Weidinger, T., Grosz, B., Pintér, K., Tuba, Z., and Führer, E.: Estimation of net nitrogen flux between the atmosphere and a semi-natural grassland ecosystem in Hungary, Eur. J. Soil Sci., 61, 631-639, 2010.

Maljanen, M., Liikanen, A., Silvola, J., and Martikainen, P. J.: Nitrous oxide emissions form boreal organic soil under different land-use, Soil Biol. Biochem., 35, 689-700, 2003.

Matthews, R. A., Chadwick, D. R., Retter, A. L., Blackwell, M. S. A., and Yamulki, S.: Nitrous oxide emissions from smallscale farmland features of UK livestock farming systems, Agric. Ecosyst. Environ., 136, 192-198, 2010.

Mészáros, R., Horváth, L., Weidinger, T., Neftel, A., Nemitz, E., Dämmgen, U., Cellier, P., and Loubet, B.: Measurement and modelling ozone fluxes over a cut and fertilized grassland, Biogeosciences, 6, 1987-1999, doi:10.5194/bg-6-1987-2009, 2009.
Mummey, D. I., Smith, J. L., and Bolton Jr., H.: Nitrous oxide flux from a shrub-steppe ecosystem: sources and regulation, Soil Biol. Biochem., 26, 279-286, 1994.

Mutegi, J. K., Munkholm, L. J., Petersen, B. M., Hansen, E. M., and Petersen, S. O.: Nitrous oxide emissions and controls as influenced tillage and crop residue management strategy, Soil Bio. Biochem., 42, 1701-1711, 2010.

Pattey, E., Strachan, I. B., Desjardins, R. L., Edwards, G. C., Dow, D., and MacPherson, J. I.: Application of a tunable diode laser to the measurement of $\mathrm{CH} 4$ and $\mathrm{N} 2 \mathrm{O}$ fluxes from field to landscape using several micrometerorological techniques, Agr. Forest Meteorol., 136, 222-236, 2006.

Pedersen, A. R., Petersen, S. O., and Schelde, K.: A comprehensive approach to soil-atmosphere trace gas flux estimation with static chambers, Eur. J. Soil Sci., 61, 888-902, 2010.

Petersen, S. O. and Sommer, S. G.: Ammonia and nitrous oxide interactions: Roles of manure organic matter management, Anim. Feed Sci. Technol., 166-167, 203-513, 2011.

Petersen, S. O., Regina, K., Pöllinger, A., Rigler, E., Valli, L., Yamulki, S., Esala, M., Fabbri, C., Syväsalo, E., and Vinther, F. P.: Nitrous oxide emissions from organic and conventional crop rotations in five European countries, Agric. Ecosyst. Environ., 112, 200-206, 2006.

Petersen, S. O., Schjonning, P., Thomsen, I. K., and Christensen, B. T.: Nitrous oxide evolution from structurally intact soil as influenced by tillage and soil water content, Soil Bio. Biochem., 40, 967-977, 2008.

Petersen, S. O., Mutegi, J. K., Hansen, E. M., and Munkholm, L. J.: Tillage effect on $\mathrm{N}_{2} \mathrm{O}$ emissions as influenced by winter cover crop, Soil Bio. Biochem., 43, 1509-1507, 2011.

Pihlatie, M., Rinne, J., Ambus, P., Pilegaard, K., Dorsey, J. R., Rannik, Ü., Markkanen, T., Launiainen, S., and Vesala, T.: Nitrous oxide emissions from a beech forest floor measured by eddy covariance and soil enclosure techniques, Biogeosciences, 2, 377387, doi:10.5194/bg-2-377-2005, 2005.

Rodrigo, A., Recous, S., Neel, C., and Mary, B: Modelling temperature and moisture effects on C-N transformation in soils: comparison of nine models, Ecol. Model., 102, 325-339, 1997.

Rochette, P.: Towards a standard non-steady-state chamber methodology for measuring soil $\mathrm{N}_{2} \mathrm{O}$ emissions, Anim. Feed Sci. Technol., 166-167, 141-146, 2011.

Rochette, P. and Eriksen-Hamel, N. S.: Chamber measurements of soil nitrous oxide flux: Are absolute values reliable?, Soil Sci. Soc. Am. J., 72, 331-342, 2008.

Schaufler, G., Kitzler, B., Schindlbacher, A., Skiba, U., Sutton, M. A., and Zechmeister-Boltenstern, S.: Greenhouse gas emissions from European soils under different land use: effects of soil moisture and temperature, Eur. J. Soil Sci., 61, 683-696, 2010.

Schjønning, P., Thomsen, I. K., Petersen, S. O., Kristensen, K., and Christensen, B. T.: Relating soil microbial activity to water content and tillage-induced differences in soil structure, Geoderma, 163, 256-264, 2011.

Skiba, U. and Smith, K. A.: The control of nitrous oxide emissions from agricultural and natural soils, Chemosphere, 2, 379-386, 2000.

Smith, K. A.: Greenhouse gas emissions, In: Hillel, D. (Ed.), Encyclopedia of soils in the environment, Elsevier Ltd, 145-153, 2004. 
Smith, K. A. and Conen, F.: Measurement of trace gases I: Gas analysis, chamber methods, and related procedures, in: Soil and environmental analysis: Modern instrumental techniques, edited by: Smith, K. A. and Cresser, M. C., 3rd edn., M. Dekker, NY, 433476, 2004.

Smith, K. A., Thomsen, P. E., Clayton, H., Mctaggart, I. P., and Conen, F.: Effects of temperature, water content and nitrogen fertilization on emissions of nitrous oxide by soils, Atmos. Environ., 32, 3301-3309, 1998.

Theobald, M. R., Akkal, N., Bienkowski, J., Bleeker, A., Boegh, E., Boissy, J., Braban, C. F., Dalgaard, T., Decuq, C., Dragosits, U., Drouet, J.-L., Durand, B., Durand, P., Fauvel, Y., Flechard, C., Frumau, K. F. A., Hamon, Y., Hensen, A., Janku, K., Kedziora, A., Kulek, B., Magliulo, E., Magliulo, P., Masson, S., Maury, O., Nowak, M., Olesen, J. E., Oliva, M., Palumbo, I., Pugesgaard, S., Schelde, K., Szczepanski, M., Vitale, L., Vogt, E., Sutton, M. A., and Cellier, P.: Strategies for measuring flows of reactive nitrogen at the landscape scale, Nitrogen \& global change key findings - future challenges, Conference proceedings, Edinburgh, 11-15 April 2011, S12-1, 2011.

Thomsen, I. K., Pedersen, A. R., Nyord, T., and Petersen, S. O.: Effect of slurry pre-treatment and application technique on shorttern $\mathrm{N}_{2} \mathrm{O}$ emissions as determined by a new non-linear approach, Agric. Ecosyst. Environ., 136, 227-235, 2010.

Thorman, R. E., Chadwick, D. R., Harrison, R., Boyles, L. O., and Matthews, R.: The effect on $\mathrm{N}_{2} \mathrm{O}$ emissions of storage conditions and rapid incorporation of pig and cattle farmyard manure into tillage land, Biosyst. Eng., 97, 501-511, 2007.
Velthof, G. L., Van Groenigen, J. W., Gebauer, G., Pietrzak, S., Jarvis, S. C., Pinto, M., Corré, W., and Oenema, O.: Temporal Stability of Spatial Patterns of Nitrous Oxide Fluxes from Sloping Grassland, J. Environ. Qual., 29, 1397-1407, 2000.

Venterea, R. T.: Simplified method for quantifying theoretical underestimation of chamber-based trace gas fluxes, J. Environ. Qual., 39, 126-135, 2010.

Vilain, G., Garnier, J., Tallec, G., and Cellier, P.: Effect of slope position and land use on nitrous oxide $\left(\mathrm{N}_{2} \mathrm{O}\right)$ emissions, Agr. Forest Meteorol., 150, 1192-1202, 2010.

Webb, J., Chadwick, D., and Ellis, S.: Emissions of ammonia and nitrous oxide following incorporation into the soil of farmyard manures stored at different densities, Nutr. Cycl. Agroecosyst., 70, 67-76, 2004.

Wohlfart, T., Exbrayat, J.-F., Schelde, K., Christen, B., Dalgaard, T., Frede, H.-G., and Breuer, L.: The importance of riparian zones on stream carbon and nitrogen export in a temperate, agricultural dominated landscape, Biogeosciences Discuss., 9, 7465-7497, doi:10.5194/bgd-9-7465-2012, 2012.

Zebarth, B. J., Rochette, P., and Burton, D. L.: $\mathrm{N}_{2} \mathrm{O}$ emissions from spring barley production as influenced by fertilizer nitrogen rate, Can. J. Soil Sci., 88, 197-205, 2008. 